\title{
The bus rapid transit system: A service quality dimension of commuter uptake in Cape Town, South Africa
}

\begin{tabular}{|c|}
\hline $\begin{array}{l}\text { Author: } \\
\text { Prince D. Ugo }\end{array}$ \\
\hline $\begin{array}{l}\text { Affiliation: } \\
{ }^{1} \text { Chesmans Trade } \\
\text { International Co., Cape Town, } \\
\text { South Africa }\end{array}$ \\
\hline $\begin{array}{l}\text { Correspondence to: } \\
\text { Prince Ugo }\end{array}$ \\
\hline $\begin{array}{l}\text { Email: } \\
\text { 209234563@mycput.ac.za }\end{array}$ \\
\hline $\begin{array}{l}\text { Postal address: } \\
\text { PO Box } 13160 \text {, Mowbray } \\
7705 \text {, South Africa }\end{array}$ \\
\hline $\begin{array}{l}\text { Dates: } \\
\text { Received: } 23 \text { June } 2014 \\
\text { Accepted: } 05 \text { Aug. } 2014 \\
\text { Published: } 28 \text { Nov. } 2014\end{array}$ \\
\hline $\begin{array}{l}\text { How to cite this article: } \\
\text { Ugo, P.D., 2014, 'The bus } \\
\text { rapid transit system: A } \\
\text { service quality dimension of } \\
\text { commuter uptake in Cape } \\
\text { Town, South Africa', Journal } \\
\text { of Transport and Supply } \\
\text { Chain Management } 8(1) \text {, } \\
\text { Art. \#145, } 10 \text { pages. http:// } \\
\text { dx.doi.org/10.4102/jtscm. } \\
\text { v8i1.145 }\end{array}$ \\
\hline $\begin{array}{l}\text { Copyright: } \\
\text { (C) 2014. The Authors. } \\
\text { Licensee: AOSIS } \\
\text { OpenJournals. This work is } \\
\text { licensed under the Creative } \\
\text { Commons Attribution } \\
\text { License. }\end{array}$ \\
\hline
\end{tabular}

\begin{abstract}
This study evaluated commuter uptake of the bus rapid transit (BRT) system in Cape Town, South Africa. As a stated preference survey was not carried out prior to the launch of the new BRT system in the City of Cape Town, it became difficult to assess commuters' preferences, which would have provided City policymakers and planners with an understanding of customer satisfaction of the proposed bus service. The commuting trend of the BRT system in the City indicates that tickets sales and utilisation by commuters is gradually picking up, but one would have expected high commuter engagement in terms of the modernity profile of the BRT system. This study investigated commuters' $(n=260)$ satisfaction levels with 30 service quality variables on a self-rated questionnaire, using quantitative research methodology. The study result showed that passengers were not satisfied with the transport fare and the availability or accessibility of ticket sales outlets. In the context of this study, this result implies that the 'responsiveness and affordability' variable of the service quality dimensions should be an area of interest and review to City of Cape Town policymakers and planners. Service quality trends in public transport were also highlighted.
\end{abstract}

\section{Introduction}

In recent decades, the focus of public transport authorities in the urban areas of South Africa was largely focused on the provision of basic services for low-income communities, whose travel choices did not extend to walking, cycling or driving to their destinations (Council for Scientific and Industrial Research [CSIR] 2005:1-2). In most medium to high-income areas, only rudimentary services exist which can barely be considered an alternative to decent public transport (CSIR 2005:1-2).

The safety of society is influenced, inter alia, by the safety and quality of its transport system, which is an essential component of infrastructure; and transport plays a significant role in that it provides access to education, trade and industry (Holtmann \& Jansen 2007:2-4). Transport quality and safety play out in a variety of ways in the public transport system and, regardless of how 'bad' or potentially dangerous the minibus taxi systems might be in South Africa, it is equally important to acknowledge the important role they play in the daily lives of low-income earners and the poor. However, some of the challenges to this system call for greater concern in requiring regulatory control and strict enforcement before improvement will be visible - this includes issues of safety, violation of the rules of the road, roadworthiness of the minibus taxi vehicles, taxi drivers' attitude, waiting time at various stops and facilities at the taxi ranks (Kane 2006).

The City of Cape Town, with features similar to other growing cities in sub-Saharan Africa, is still faced with minibus taxi operators which have an ineffective quality service framework, which employ untrained drivers, which are motivated by daily or weekly revenue targets that are remitted to bus owners, which are characterised by lack of safety for passengers (Kanyama, Linden \& Lupala 2004; Nkurunzia et al. 2012), which do not run on schedule and which consistently follow the line of least resistance through the townships and settlements, in order to maximise the number of journeys and thus their profits (CSIR 2005:1-2).

As a viable public transport alternative, the City of Cape Town introduced the bus rapid transit (BRT) system, beginning in 2010. This study evaluated commuter uptake of the BRT system, using the City of Cape Town's MyCiTi bus service as a case study.

\section{Background}

The City of Cape Town has a population of 3.74 million people (Statistics South Africa 2012b:4993) and the commuting trend of the BRT system in the City indicates that tickets sales and 
utilisation by commuters is being taken up more slowly when compared to the commuting and ridership pattern in most cities that have implemented a BRT system (Table 1). The policymakers, City administrator and general public would have expected high commuter uptake in terms of the high modernity profile of the BRT system, but the integrated rapid transit (IRT) project status and progress statistics for the City of Cape Town indicate that the average passenger journey on ticket sales (Figure 1) for each month from the launch of the MyCiTi bus BRT system in May 2010 until February 2013 witnessed 320000 passenger trips on the routes that were operational at the time (City of Cape Town 2013:40-43).

However, the comparatively slower commuter uptake of BRT services should not be seen as an indication of the failure of the BRT system, or that commuters are simply uninterested in using the system. In the opinion of the author, it is commendable and encouraging, considering existing competitors and especially within the context of the historical context of Cape Town and South Africa in general. A newly launched transport venture such as MyCiTi bus would require optimisation strategies with medium and long-term goals to ensure a sustainable uptake and return on investment. This seems to be the case, as what is unique about MyCiTi bus is the determination on the part of the City to continuously roll out new routes, which has significantly grown the ridership to 761000 as of February 2014 (MyCiTi 2014). This was as a result of removing minibus taxi and existing bus services in some of the areas.

Nevertheless, because a stated preference survey was not conducted prior to the launch of the BRT system, it became difficult to realise commuters' preferences, which would have provided City policymakers and planners with an understanding of how to achieve greater customer satisfaction - and therefore a larger commuter uptake - in the proposed bus service.

\section{Objectives}

The primary research objectives of this study are to:

- Determine the commuter satisfaction of BRT services in Cape Town.
- Establish the service quality variables responsible for low commuter uptake of BRT services.

- Provide an analysis of service quality variables for the BRT system.

\section{Literature review}

\section{The bus rapid transit system}

Many cities in the world are searching for ways to address their urban transportation challenges (Adebambo \& Adebayo 2009:106-199) ranging from traffic congestion to road safety and environmental issues (Mobereola 2009). Modern viable alternative transportation options have grown in recent years to include BRT systems (Adebambo \& Adebayo 2009). This system is defined by Levinson et al. (2003:10-26) as 'a flexible, rubber-tired form of rapid transit that combines stations, vehicles, running ways and information technology elements into an integrated system with a strong identity'. A BRT system integrates flexibility and low-cost features and continues to exhibit modernity and technology in comparison to the minibus taxi (Mfinanga \& Ochieng 2006:35-52); the advantage of the BRT system over a minibus taxi is, inter alia, the operation of longer buses on dedicated bus lanes, thereby offering passengers a regular, faster, safer and congestion-free drive

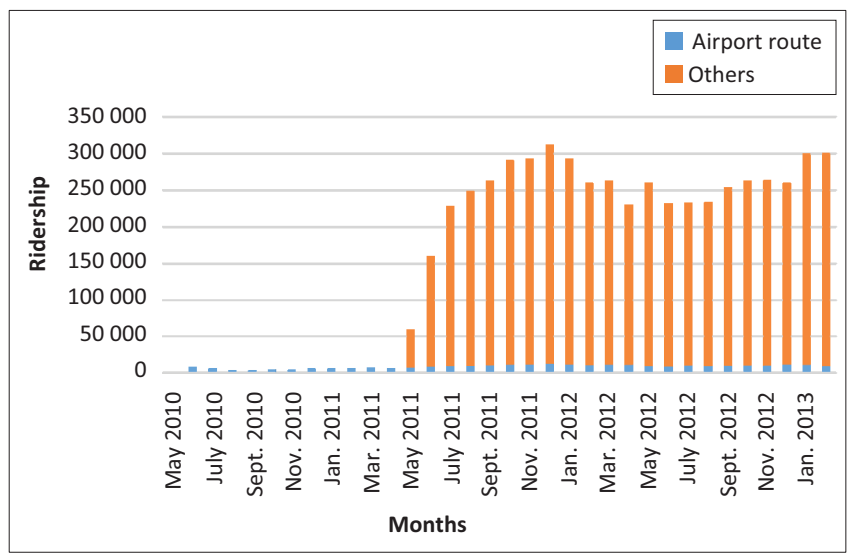

Source: City of Cape Town, 2013, Integrated rapid transit: Project status and progress report 36, City of Cape Town, Cape Town, pp. 40-43

FIGURE 1: Total number of passenger journeys on MyCiTi bus services, May 2010 - February 2013.

TABLE 1: Bus rapid transit system in some cities around the world.

\begin{tabular}{|c|c|c|c|c|c|c|}
\hline Brand & Name & Country & City & Population in millions & Daily ridership & Monthly \\
\hline \multirow[t]{7}{*}{ BRT brand name } & Adelaide & Australia & Adelaide & 1.1 & 30000 & 900000 \\
\hline & Assis Brasil Busway & Brazil & Porto & 3.4 & 290000 & 8700000 \\
\hline & Blok M Kota Line 1 & Indonesia & Jakarta & 9.8 & 100000 & 3000000 \\
\hline & BRT Lite & Nigeria & Lagos & 15.0 & 195000 & 5850000 \\
\hline & Metrobus EI Trole & Ecuador & Quito & 1.8 & 240000 & 7200000 \\
\hline & Transmileno & Colombia & Bogotá & 7.0 & 1300000 & 39000000 \\
\hline & Megabus & Colombia & Pereira & 0.7 & 45000 & 1350000 \\
\hline & Assis Brasil Busway & Brazil & Porto & 3.4 & 290000 & 8700000 \\
\hline & Blok M Kota Line 1 & Indonesia & Jakarta & 9.8 & 100000 & 3000000 \\
\hline & BRT Lite & Nigeria & Lagos & 15.0 & 195000 & 5850000 \\
\hline & Metrobus EI Trole & Ecuador & Quito & 1.8 & 240000 & 7200000 \\
\hline & Transmileno & Colombia & Bogotá & 7.0 & 1300000 & 39000000 \\
\hline & Megabus & Colombia & Pereira & 0.7 & 45000 & 1350000 \\
\hline
\end{tabular}

Source: Adapted from Mobereola, 2009, Africa's first bus rapid transit scheme: The Lagos BRT-lite system, Sub-Saharan Africa Transport Policy Program Discussion Paper 9 , SSATP, Lagos BRT, bus rapid transit. 
(Hensher, Stopher \& Bullock 2003:499-517). Rapid transit is not a mode of transport; it is a means or system of mass transportation that provides a faster service than available alternatives, mostly with a mean speed of $50 \mathrm{~km} / \mathrm{h}$ or more and with a dedicated right of way (Iles 2005:25-26). The BRT system is operating successfully around the world (International Association of Public Transport [UITP] 2010) in cities such as Lagos, São Paulo, Johannesburg, Curitiba, Bogota, Beijing, Los Angeles and Taipei and continues to show that with functional and successful implementation, it can become a quality mass transit system (Adebambo \& Adebayo 2009) that is capable of serving daily travel needs at affordable rate to commuters (UITP 2010). However, the challenge lies in the fundamental development of an affordable BRT system that will not only meet transit objectives, but will do so without sacrificing service quality and commuter satisfaction.

\section{The bus rapid transit system in Johannesburg}

The population of the City of Johannesburg is 4.4 million (Statistics South Africa 2012a:2-10) and an analysis of commuter uptake of the BRT system in Johannesburg reveals it is higher than most of the cities in Table 1, including Cape Town. In Johannesburg, the BRT is called 'Rea Vaya' and figures from ticket sales between January 2009 and July 2010 show a significant increase in ridership, with Traffic Management Technologies of South Africa recording total ticket sales of 548 175, whilst the independent vendors ticket sales stood at 414800 (Greuning 2012). The combined monthly ticket sales for this period was 962975 , which is three times more than the average monthly sales trend relative to other cities in South Africa. Currently, more than 40000 commuters travel on Rea Vaya daily, bringing the total ridership to 1.2 million per month.

However, it is important to note that the information and references to ridership in this study provide an overview of the BRT system in some cities and should not be taken necessarily as an 'apple-to-apple' comparative analysis, because of, inter alia, variation in population density, distance of transport corridors and the urbanisation profile of the various cities. It does, however, serve to stimulate policymakers that BRT is an efficient transport system that can be used as a viable alternative transport in African cities.

\section{MyCiTi bus services in Cape Town}

In 2007, the City of Cape Town announced the introduction of a new bus service (Eichhom 2013). This was necessitated by, inter alia, Cape Town's role as one of the host cities of the 2010 FIFA World Cup, as City administrators pondered that match-day transportation requirements were crucial as a host city. Consequently, a huge capital injection by the National Treasury provided the financial base (MyCiTi 2013). The first phase of the system assisted the City to meet the public transport requirements for hosting the World Cup. Whilst this initial work is primarily a
BRT system, it is also tailored in a way that emphasises the need for integration with other modes of transport, with emphases on rail, which is regarded as the pillar of public transport in Cape Town and South Africa in general (MyCiTi 2013).

In line with the integrated public transport network model that is supported by the National Land Transport Act (Act No. 5 of 2009) (Republic of South Africa 2009), the City of Cape Town was inspired and motivated to not only improve public transport, but to transform the sector totally. Since 2007, the City of Cape Town has been working on the initial phase of an IRT system in Cape Town (MyCiTi 2013), which is aimed at significantly improving public transport in the 'Mother City'. The commencement of this IRT system was the dedicated work on the MyCiTi BRT system (City of Cape Town 2013:40-43) and the City continues implementing the MyCiTi bus service in phases. The first IRT construction contract was awarded on the 06 October 2008 (City of Cape Town 2010). Planned phase $1 \mathrm{~A}$ is divided into four milestones, with November 2013 as the projected completion timeline, whilst the phase $1 \mathrm{~B}$ projected completion date is October 2014, subject to availability of funding (City of Cape Town 2012).

\section{Service quality in public transport}

The concept of service quality has been broadly applied to the public transport system and defined as commuters' perception of how well a particular transport service meets or exceeds their expectation (Nandan \& Geetika 2010:97-112). Service quality in the public transport sector can be measured in relationship with customer's expectations, perceptions, satisfaction and attitude (Litman 2008:43-62); it encompasses several topics such as comfort inside and outside of the vehicle, journey duration and the existence of infrastructural support systems (Currie 2005:41-53).

A holistic approach to service quality improvement in the public transport system is required, particularly in the identification of customer's needs and priorities, including use of complaints and feedback to evaluate necessary service quality indicators (Dell'Olio, Ibeas \& Cecin 2010:388-396). Public transport usually competes with other modes of transportation (Currie 2005:41-53) and will definitely be utilised if it can meet the expectations of the commuters, specifically if it can deliver the accessible, safe, affordable and reliable service it claims to provide (Stradling et al. 2007:283-289).

A review of literature on public transport quality indicates that service quality in the public transport sector reflects commuters' perceptions of the transport system's performance (Hensher et al. 2003; Wallis \& Currie 2008). In a journey, commuters generally have a choice between modes of transport, each with unique features interwoven with pros and cons (Garling 2005). Customers' expectations and perceptions are paramount to service quality (Davidoff 1994); they are not objective and may also not based on reality 
(Ungerer \& Daweti 2007). If a customer expects a certain level of service and they perceive that an equal or higher level was delivered, they will most definitely be satisfied (Vavra 1997); however, even when good service as measured by an objective standard is delivered and customers expected better service, they will be dissatisfied (Ungerer \& Daweti 2007). An aspect that is a major determinant in service quality is customer expectations (Foster 2013); these are formed by the customers in what is called the 'moment of truth' (Ungerer \& Daweti 2007). A moment of truth is any contact between a customer and a business whereby a positive or negative judgement about the service received is formed (Moreo 1996). Therefore, when a customer expects something to happen that will make them come back, it should happen (Foster 2013; Ungerer \& Daweti 2007) and the moment of truth always will result in either happy customers or lost customers (Foster 2013). These moments of truth therefore are the moments that ultimately determine whether or not a company will succeed from a sustainable business point of view (Davidoff 1994).

A comprehensive understanding of user perceptions of service quality provided by the system is tantamount to realisation of the primary objectives of the transport system (Nkurunzia et al. 2012:95-101). Further research alluded to the fact that the importance each commuter places on public transport service attributes is directly proportional to their service quality experiences (Foote, Stuart \& Elmore-Yalch 2001:93-100) and the desire to improve the public transport services to meet the increasing needs and expectations of commuters has been one of the primary goals set to be achieved by the urban transport planners globally (Delbosc \& Currie 2011; Ji \& Gao 2010; Mfinanga \& Ochieng 2006).

Thus, a widely recognised and acceptable set of service quality variables that was used to measure commuter satisfaction in this study is as follows (McKnight, Pagano \& Paaswell 1986:423-441; Parasuraman, Zeithaml \& Berry 1985:40-49; Zeinthaml, Bitner \& Grembler 2006):

- Tangibles: This includes, inter alia, the physical features of the service facility, the equipment, personnel and communication materials.

- Service reliability: This variable differs from the reliability of the service, in that it relates to the ability of the service provider to perform the promised service dependably and accurately.

- Responsiveness and affordability: This is the willingness of service provider to be helpful and prompt in providing service, for example when customers complain of high transport fare, did operators consider a downward review of fare? When commuters phone a transport company for any enquiry, how long did it take for a response? Was the query taken care of quickly and without forwarding calls to another location, or placing the caller on hold whilst they listen to music and adverts for hours? The same questions, amongst others, can be applied to various service sectors to measure their level of responsiveness.
- Assurance: This refers to the knowledge and courtesy of employees and their ability to inspire trust and confidence.

- Empathy: Consumers of services desire empathy; this service dimension entails that customers desire caring, individualised attention from a service firm.

\section{Customer satisfaction indicators}

The key to customer retention is customer satisfaction (Hennig-Thurau \& Klee 1998:737-761). Customer satisfaction is usually a self-reported assessment of how much customers like a company and how happy they are with goods purchased or services obtained from the company (Klein 2014). However, customer satisfaction and loyalty are interwoven and the measurement of loyalty is based on the likelihood to purchase again or not migrate to a competitor (Boulding et al. 1993). Customer satisfaction is strongly associated with how a customer feels about his or her previous transaction (Klein 2014). It can be a fast-growing phenomenon and can disappear even faster after a bad service transaction experience (Ungerer \& Daweti 2007).

Most studies previously conducted have shown that higher levels customer satisfaction leads to greater customer loyalty (Barabino et al. 2012:238-252; Beirao \& Cabral 2007:478-489; Dhingra 2011; Eboli \& Mazulla 2007:30-42; Jaisal 2008:405-416; Javid et al. 2013:461-472; Mokonyama 2012:1-17; Zeinthaml et al. 2006), whilst Blose and Tankersley (2004:75-89) argued that providing services on time and meeting commitments as promised will greatly influence a customer perception and satisfaction, as well as increase customer loyalty (Brink \& Berndt 2005; Bruhn \& Georgi 2006; Ekinci 2004:197-203), which leads to a reduction in the operational cost of future transactions (Reichheld \& Sasser 1990:105-111). In any business transaction, if an organisation makes an avoidable mistake that leads to failure in delivery of quality services, it demoralises the customers' confidence and consequently leaves a negative imprint on the business service quality performance (Fen \& Lian 2007:59-72; Malhotra 2010). Customer satisfaction is mostly viewed from a psychological point of view, which involves the feeling of well-being and a pleasure that results from obtaining an appealing product and or service (World Tourism Organization 1985). Customer satisfaction should be a fundamental performance indicator of businesses because of its links to the behavioural and economic pattern of businesses (Anderson, Fornell \& Rust 2001:129-145). Customers subconsciously evaluate businesses not only on the basis of whether they obtain what they want but on the strength of meeting the following six basic customer needs (Leland \& Bailey 1995):

- Friendliness: This is the most basic of all customer needs and is usually associated with being greeted politely and courteously.

- Understanding and empathy: Customers need to feel that the service person appreciates and understands their circumstances and feelings without criticising them. 
- Fairness: The need to be treated fairly is important to most customers.

- Control: This represents the customer's need to feel that he or she has control over what happens in the service encounter.

- Options and alternatives: Customers need to feel that other avenues are available to assist them in achieving what they want to accomplish.

- Information: Customers need to be educated and informed about the product, policies and procedures they encounter when dealing with a specific company.

What is paramount in the above customer needs is that customers do not ask for these needs, yet miss them when they are not provided (Ungerer \& Daweti 2007); thus, customer satisfaction is a satisfaction based on processes (Vavra 1997).

\section{Modal competitiveness in public transport}

Modal competitiveness in public transport cannot be dealt with in isolation; competition does not exist between modes per se but on the ability of the operators to attract more commuters consistently over time. The rate of competition between transport modes depends on, inter alia, factors such as safety, comfort and reliability (Finn \& Mulley 2011:89107; Mazulla \& Ebloi 2006:42-53), but these factors are mostly not an issue in developing countries where better alternatives simply do not exist. For example, passengers that use minibus taxis often do so for reasons other than an opinion regarding the mode; it can be for basic convenience of the mode, as opposed to safety, reliability and comfort (Barabino, Deiana \& Tilocca, 2012:238-252; Govender 2014:317-326).

Competitiveness of BRT versus other transport modes poses a challenge, especially with rail, because of loading patterns, designs and carrying capacities (Henser \& Golob 2008:501-518; Hildalgo \& Graftieaux 2008:77-88). The comparisons of passenger capacities are made even more challenging by large variations amongst BRT systems, for example, whilst 45000 passengers per direction per hour is achieved in the case of Bogotá, other busway systems average only one tenth this passenger volume, with even lower peak hourly throughputs at an average of 1000 passengers in cities such as Cape Town, Amsterdam and Changde (Cervero 2013:1-31). In practice, the carrying capacities of BRT systems are lower, as found in the crunchload ridership of various BRT systems, which ranges from 2000 to 8000 passengers per direction per hour (Cervero 2013:1-31; Cervero, Murakami \& Miller 2010:1-7). Thus the line capacities of BRT relative to urban rail, and its costeffectiveness, could also be overrated (Cervero 2013:1-31; Currie 2006:1-21; Duarte \& Rojas 2012:1-18). The costeffectiveness edge of BRT is also hindered to the extent that large-scale rail networks provide greater connectivity and accessibility at faster travel speeds, in addition to having vigorous city-shaping impacts than the more constrained range of BRT systems (Cervero 2013:1-31).
Yet, passenger rail is a relatively inflexible mode and it also has significantly low rapid accessibility when compared with minibus taxis, in relation to urban dynamics and sprawl (Agunloye 2011:443-448; Mashiri, Moeketsi \& Baloyi 2010), thus the taxi industry was particularly effective at competing for the off-peak market, especially in the city edge and townships (CSIR 2005). Low volumes in the off-peak periods meant that even infrequent trains were largely empty (Finn \& Mulley 2011:89-107; Ryneveld 2008) and the same can be said about the BRT in most cities, especially cities with a low population density in transport corridors. This implies that minibus taxis were much better at serving the market within such periods (Ryneveld 2008). However, high return on investment in public transport, as with other transport systems, is mostly determined by peak demand (Agunloye \& Oduwaye 2011:98-103; Andaleeb, Haq \& Ahmed 2007:1-25; Ryneveld 2008; Schade \& Schlag 2003:45-61). Where there is a high peak-to-base demand ratio, significant investments will ultimately lie dormant during off-peak intervals. By more successfully serving the off-peak market, minibus taxis were able to maximise their demand profile during the day and thereby reduce their peak-to-base ratio, at the same time aggravating the ratio for trains (Ryneveld 2008), as well as the BRT system in cities that are yet to implement integrated rapid transit schemes. Therefore, partly as a result of the profound competitiveness of minibus taxis with BRT, cities such as Cape Town and Johannesburg are removing buses along the BRT corridors, as mentioned above, and this strategy has yielded positive results in terms of an increase in ridership.

\section{Managing urban dynamics through efficient transport systems: Lesson from Curitiba}

Curitiba is the capital city of the State of Paraná in southern Brazil, located about $250 \mathrm{~km}$ south-west of São Paulo (Goodman, Laube \& Schwenk 2006:75-76). The success of the Curitiba BRT infrastructure has been extensively articulated in various academic literature and policy documents globally, therefore it will not be overemphasised in this paper, but from Curitiba's urban dynamics perspective, BRT was seen as not only a transportation investment but also an opportunity to redirect and shape urban growth (Suzuki, Cervero \& Luchi 2013) in a more sustainable and transit-oriented manner (Cervero 2006; Cervero \& Kang 2011). There were zoning reforms, pro-development tax policies, assistance with land assemblage and supportive infrastructural investments at local government level, with a clear mandate that all medium and large-scale urban development be positioned along a BRT corridor (Cervero 2013:1-31; Duarte \& Ultramari 2012:183-194). A design element used to enhance transit accessibility in Curitiba was what is popularly referred to as 'trinary' (Goodman et al. 2006:75-76), which is a three parallel roadway system with compatible land uses and building heights that align with the distance from the BRT corridor (Santos 2011). An important benefit of mixed land uses and transit service levels along these corridors, including the high ridership rates in Curitiba, has balanced bidirectional flows, which ensures efficient and effective use of bus capacity. Thus, the higher population density of the city supported by 
the trinary design has translated directly into higher ridership (Cervero 2013:1-31).

High transit use has also considerably reduced the city's environmental footprint; it has the cleanest air in relation to any Brazilian city (Suzuki et al. 2010). The integration of rapid transit and land use has been a work in progress that spans over 40 years and the sustainability of a bus-based transit system with a mixed land use settlement pattern, as seen in Curitiba, is a lesson for cities globally, especially in developing countries.

\section{Research method and design}

In the context of this study, a self-rated questionnaire was used to collect the primary data, which were later organised, analysed and interpreted using SPSS statistical software, version 22 (2013). The collection of a large quantity of evidence, usually numeric, and which will be converted to statistical data, is possible by means of questionnaires and interviews (Remenyi et al. 2009). The questionnaire was based on well-published and tested service quality variables or dimensions, as earlier stated, and these variables were expanded to 30 transport service quality statements. As of May 2014, 26 operational bus routes were covered in the survey, in which 10 respondents for each, both male and female, were selected by means of stratified sampling to produce a total of $n=260$ in the study.

The specific target respondents were selected as a result of their homogeneity in commuting preferences, which in this study is MyCiTi busses. Descriptive statistics, reliability and validation of internal consistencies (Cronbach's alpha) were performed and the results are presented in Table 2. The reliability coefficient normally ranges between 0 and 1.0 and the closer Cronbach's alpha is to 1.0, the greater the internal consistence of the items in the scale (Collis \& Hussey 2009).

TABLE 2: Distribution of responses to service quality variables of bus rapid transit in the City of Cape Town.

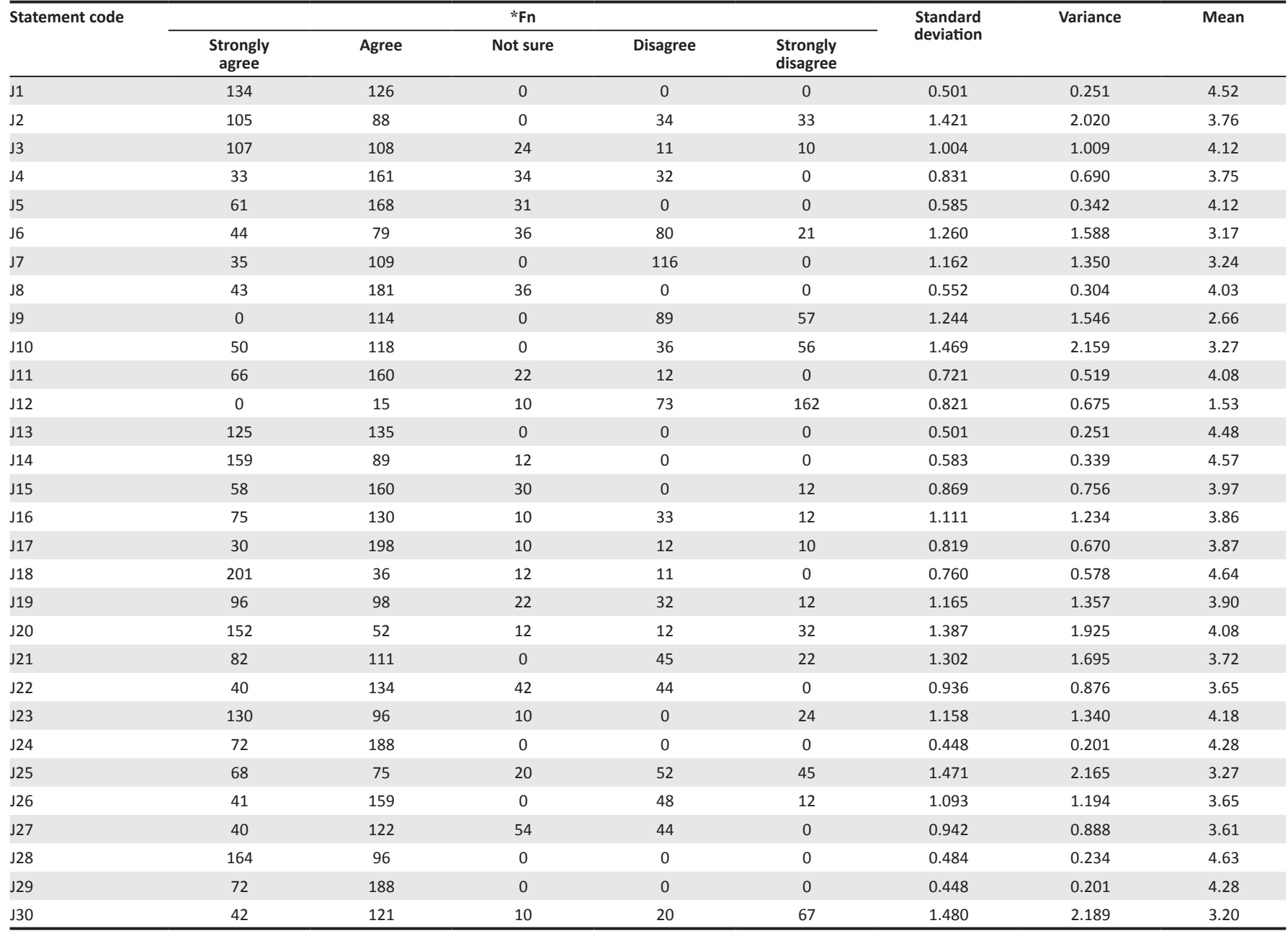

Statement and codes: J1, Inside of the bus are neat always; J2, There are comfortable seats in the bus; J3, The bus service is frequent; J4, The waiting time at the stop is short; J5, The facilitie inside the buses and station are functioning; $\mathrm{J6}$, Bus stop shelter can accommodate lots of commuters; J7, There is enough space inside the buses; J8, The buses are well maintained; J9, Bus ticket sales outlets are within reach and visible; J10, There is enough leg-room in buses; J11, More than one bus supplies the route; J12, The transport fare is affordable; J13, Commuters are comfortable with safety in the bus; J14, There is security in the buses and station; J15, The buses provide a shorter commuting time; J16, The bus drivers are well behaved; J17, Operators and drivers attend to complaints; J18, The buses spend less time at the bus stop; J19, Operators provide services when they promise to do so; J20, There is individualised attention in the bus services; J21, Operators understand the specific needs of commuters; J22, Travel schedules of buses are consistent; J23, Buses are not faulty on transit; J24, Bus tickets are always available; J25, The bus ticket sales points understand the specific needs of commuters; $\mathrm{J22}$, Travel schedules of buses are consistent; J23, Buses are not faulty on transit; J24, Bus tickets are always available; J25, The bus ticket sales points
charge extra fees for services; J26, The bus ticket is convenient to use; J27, Information on the bus services is available in official languages; J28, Drivers always obey traffic regulations; J29, There charge extra fees for services; $J 26$, The bus ticket is convenient to

$n=260$

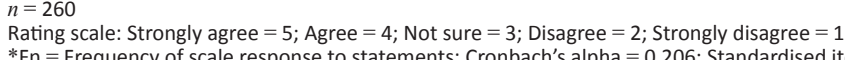

${ }^{*} \mathrm{Fn}=$ Frequency of scale response to statements: Cronbach's alpha $=0.206$; Standardised item $=0.181$. 


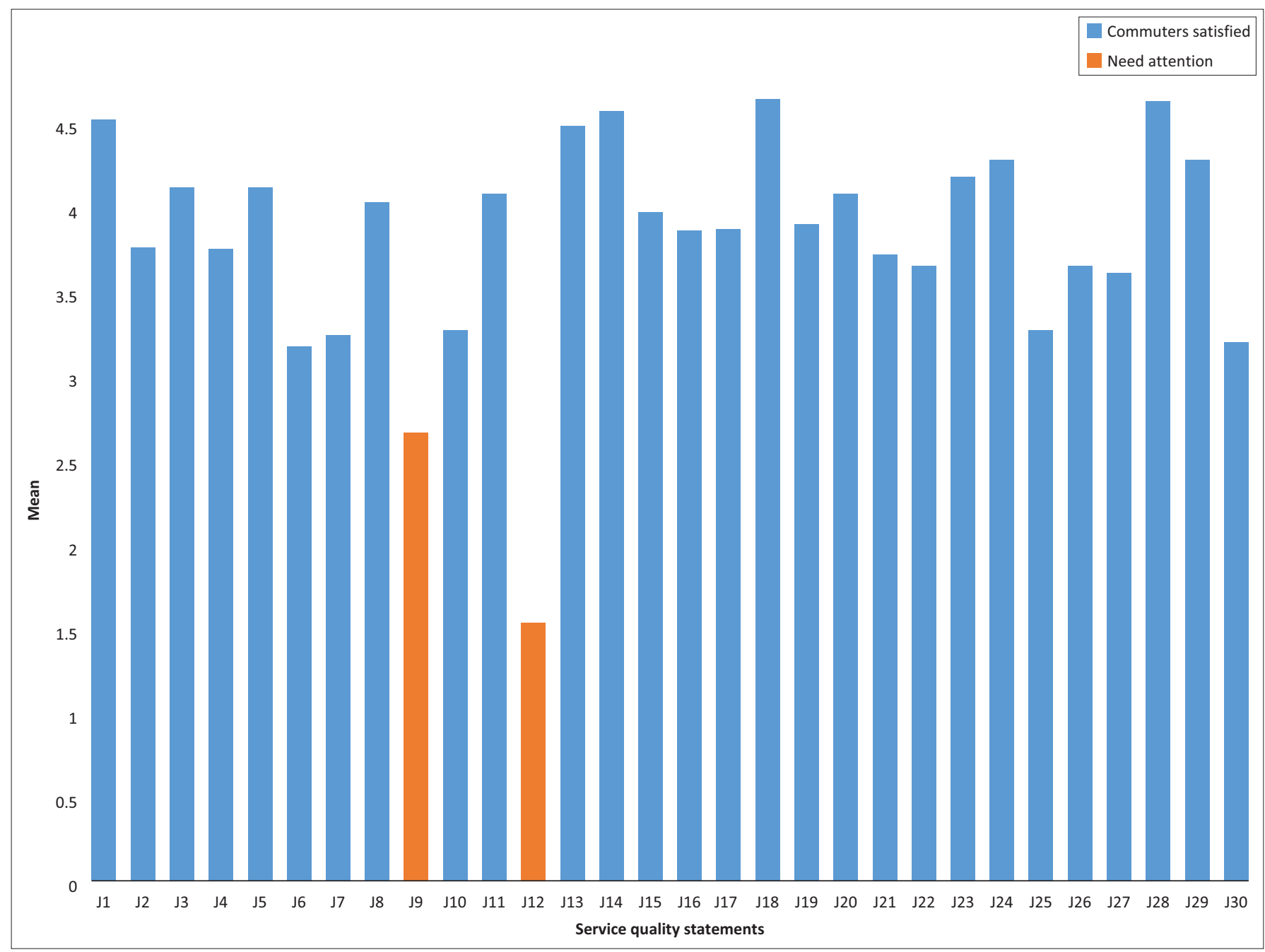

Statement and codes: $\mathrm{J} 1$, Inside of the bus are neat always; $\mathrm{J} 2$, There are comfortable seats in the bus; $\mathrm{J3}$, The bus service is frequent; J4, The waiting time at the stop is short; $\mathrm{J} 5$, The facilities inside the buses and station are functioning; J6, Bus stop shelter can accommodate lots of commuters; J7, There is enough space inside the buses; J8, The buses are well maintained; J9, Bus ticket sales outlets are within reach and visible; J10, There is enough leg-room in buses; J11, More than one bus supplies the route; J12, The transport fare is affordable; J13, Commuters are comfortable with safety in the bus; J14, There is security in the buses and station; J15, The buses provide a shorter commuting time; J16, The bus drivers are well behaved; J17, Operators and drivers attend to complaints; J18, The buses spend less time at the bus stop; J19, Operators provide services when they promise to do so; J20, There is individualised attention in the bus services; J21, Operators understand the specific needs of commuters; J22, Travel onsit; J24, Bus tickets are always available; J25, The bus ticket sales points charge extra fees for services; J26, The bus ticket is conven

to use; J27, Information on the bus services is available in official languages; J28, Drivers always obey traffic regu

In the self-rated questionnaire, the respondents were asked to respond to statements by rating service quality variables of the BRT system in the City of Cape Town which influence their overall commuting satisfaction. The rating parameter was a Likert five-point scale, with strongly disagree $=1$, disagree $=2$, not sure $=3$, agree $=4$, and strongly agree $=5$. The researcher then added all the ratings $(5+4+3+2+1=15$ points) for each of the 30 service quality variables statements.

The mean cut-off point was determined by adding the Likert scale point values and divided by the sum of scale points. This implies that:

$Q=\sum \frac{f x}{N}$

[Eqn 1]

where $Q=$ mean, $\sum=$ sum, $f x=$ frequency of $x$ and $N=$ the occurrence of points. When this was solved we arrived at:

$Q=\sum \frac{f x}{N}=\frac{15}{5}=3.0$

[Eqn 2]
Thus, a mean that is above 3.0 in the data analysis indicates strong commuter satisfaction and any mean that is below indicates low satisfaction, whilst a mean that is precisely 3.0 signifies an indecision or uncertainty with the measured transport service quality variables of the BRT in the City of Cape Town. The mean distribution of response to statements (Figure 2), including the result overview (Figure 3), were used by the author to highlight the results distribution and classification of the service quality variables.

\section{Results}

In the study analysis, the overall passenger satisfaction of the BRT transport fare (mean $1.53<3.0$; s.d. $=0.82$, variance $=$ $0.68)$ strongly disagrees that the fare is affordable. Passengers were also dissatisfied that the ticket sales outlets are not within reach and/or visible, as response to this variable shows $($ mean $=2.66<3.0 ;$ s.d. $=1.24$, variance $=1.55)$ and these fall within the 'Responsiveness and affordability' service quality variable. The other statements linked to the 'Service reliability', 'Tangibles', 'Assurance' and 'Empathy' 


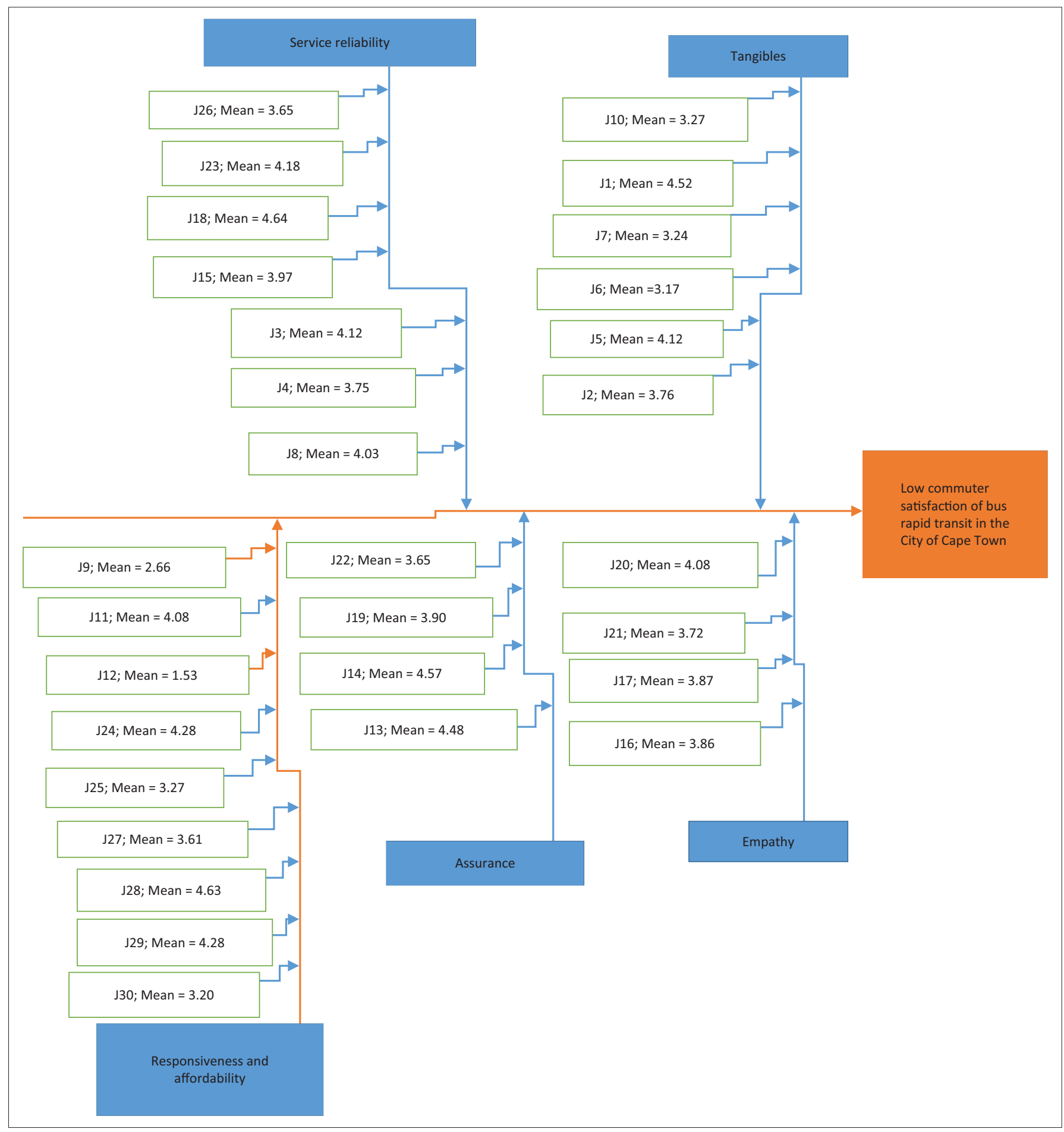

Blue boxes are the service quality variables from which the statements were derived; Green boxes show the mean values of the service quality statements measured; Orange arrows denote the problem area(s) that need attention; Blue arrows indicate higher commuter satisfaction on the measured variable statements.

FIGURE 3: Result overview - service quality variables and mean classification.

variables showed significantly higher mean $>3.0$, as depicted in Figure 3 and data provided (Table 2). Generally, the findings indicated that MyCiTi bus ticket sales outlets not being within reach or visible ('not visible' in this research context implies insufficient signage or branding of ticket retail outlets), as well as high transport fares are the dominant factors that adversely affect commuter uptake of the BRT system in the City of Cape Town. The author's findings and summary was specifically focused on analysing the primary research objectives that sought to determine the commuters' levels of satisfaction of BRT services, establish the service quality variables responsible for low commuter uptake of the BRT and provide an analysis of service quality variables for the BRT system; therefore, further statistical analysis was not deemed necessary within the ambit of the study as these objectives has been achieved. 


\section{Limitations of the study}

Despite the ability of findings presented in this study to improve BRT ridership, the study does have limitations. The primary focus was on service quality that measured commuter uptake of BRT system in Cape Town, South Africa, but the operational constraints perspectives of the MyCiTi bus service, including issues such as urban dynamics and sprawl pattern in Cape Town, was, however, excluded. Perhaps if combined with service quality measurements, these factors would have elucidated other salient findings that had impacted on the slow uptake of the BRT system. This is therefore a recommendation for future research.

\section{Conclusion}

This study has shown that commuters are satisfied in most areas of the service quality variables provided by the City of Cape Town. Out of 30 statements, only two variables (J9 and J12) that formed part of the 'Responsiveness and affordability' dimension of service quality showed the most dissatisfaction amongst commuters. If, inter alia, these areas are reviewed and improved, the ridership and commuting pattern should, by and large, improve. Rolling out new routes will not necessarily increase commuter satisfaction and increase ridership on existing routes, but it will obviously increase total number of commuters for statistical purposes. The study provides areas for improvement that will enhance ridership and sustainable return on investment to the City of Cape Town. Cities that have successfully implemented the BRT system and introduced fares within a societal context, taking into account local demographics, and engaged in comprehensive marketing have seen higher ridership and sustainability of returns. City development planning should incorporate BRT corridors in mega projects from the feasibility study stages, such as the N2 gateway housing project, and the broader spectrum of the National Development Plan in greater South Africa as part of the integrated rapid transit infrastructure. The City of Cape Town policymakers and planners should intensify their marketing strategies in order to bring awareness to the public about the services that the BRT provides and, most importantly, to provide information on where to purchase the myconnect cards, which this study has shown is the primary item of dissatisfaction amongst commuters. Notwithstanding the perceived high transport cost, if a commuter finds it difficult to purchase a travel ticket (myconnect cards) or even reload existing ones, they will automatically be lost as customers. The significance of this study is the identification some of the factors that have contributed adversely to the low commuter uptake of MyCiTi BRT service in the City of Cape Town from a service quality perspective.

\section{Acknowledgements}

The author would like to thank Dr Ben Nnaemeka, Ms Claudia Struwig and Mr Balogun Kayode for their valuable comments. The feedback from the anonymous peer-reviewers is also highly appreciated.

\section{Competing interests}

The author declares that he has no financial or personal relationships that may have inappropriately influenced him in writing this article.

\section{References}

Adebambo, S. \& Adebayo, I., 2009, 'Impact of bus rapid transit system (BRT) on passengers' satisfaction in Lagos Metropolis, Nigeria', International Journal of Creativity and Technical Development 1(3), 106-119.

Agunloye, O., 2011, 'Analysis of travels of public transport passengers (road) in lkorodu, Lagos, Nigeria', Journal of Geography and Regional Planning 4(7), 443-448.

Agunloye, O. \& Oduwaye, L., 2011, 'Factors influencing the quality of rail transport service in metropolitan Lagos', Journal of Geography and Regional Planning 4(2),
$98-103$.

Andaleeb, S., Haq, M. \& Ahmed, R., 2007, 'Reforming inner city bus transportation in developing countries: A passenger-driven model', Journal of Public Transportation 10(1), 1-25.

Anderson, E., Fornell, C. \& Rust, R., 2001, 'Customer satisfaction, productivity and profitability', Marketing Science 16(2), 129-145. http://dx.doi.org/10.1287/ mksc.16.2.129

Barabino, B., Deiana, E. \& Tilocca, P., 2012, 'Measuring service quality in urban bus transport: A modified SERVQUAL approach', Internationa Journal of Quality and Service Sciences 4(3), 238-252. http://dx.doi. org/10.1108/17566691211269567

Beirao, G. \& Cabral, J., 2007, 'Enhancing service quality in public transport system', Journal of Transport Policy 14, 478-489.

Blose, J. \& Tankersley, W., 2004, 'Linking dimensions of service quality to original outcomes', Managing Service Quality 14(1), 75-89. http://dx.doi. org/10.1108/09604520410513686

Boulding, W., Kalra, A., Staelin, R. \& Zeithaml, V., 1993, 'A dynamic process model of service quality: From expectations to behavioural intention', Journal of Marketing Research 30, 7-27. http://dx.doi.org/10.2307/3172510

Brink, A. \& Berndt, A., 2005, Customer relationship management and customer service, Juta \& Co. Ltd, Lansdowne.

Bruhn, M. \& Georgi, D., 2006, Service marketing: Managing the service value chain, Pearson Education, London.

Cervero, R., 2006, The property value case for transit. Developing around transit: Strategies and solutions that work, Urban Land Institute, Washington, DC.

Cervero, R., 2013, Bus rapid transit (BRT) an efficient and competitive mode of public transport, ACEA Scientific Advisory Group, Berkeley, pp. 1-31.

Cervero, R. \& Kang, C., 2011, 'Bus rapid transit impacts on land use and land values in Seoul, Korea', Transport Policy 18, 102-116. http://dx.doi.org/10.1016/j. tranpol.2010.06.005

Cervero, R., Murakami, J. \& Miller, M., 2010, 'Direct ridership model of bus rapid transit in Los Angeles county', Transportation Research 2145, 1-7.

City of Cape Town, 2010, Integrated rapid transit: Project summary report 11, City of Cape Town, Cape Town, pp. 4-29.

City of Cape Town, 2012, Integrated rapid transit: Project status and progress report 32, City of Cape Town, Cape Town, pp. 7-32.

City of Cape Town, 2013, Integrated rapid transit: Project status and progress report 36, City of Cape Town, Cape Town, pp. 40-43.

Collis, J. \& Hussey, R., 2009, Business research: A practical guide for undergraduate and postgraduate students, Macmillian, Palgrave.

Council for Scientific and Industrial Research (CSIR), 2005, Red book: Guidelines for human settlement planning and design, CSIR Press, Pretoria, pp. 1-2

Currie, G., 2005, 'The demand performance of bus rapid transit', Journal of Public Transportation 8, 41-53.

Currie, G., 2006, 'Bus transit oriented development: Strengths and weaknesses relative to rail', Journal of Public Transport 9(4), 1-21.

Davidoff, D., 1994, Contact: Customer service in the hospitality and tourism industry, Prentice Hall, Englewood Cliffs.

Delbosc, A. \& Currie, G., 2011, 'Understanding bus rapid transit route ridership drivers: An empirical study of Australian BRT system', Journal of Transport Policy 18, 755-762. http://dx.doi.org/10.1016/j.tranpol.2011.03.003

Dell'Olio, L., Ibeas, A. \& Cecin, P., 2010, 'Modelling user perception of bus transit quality', Journal of Transport Policy 17, 388-396. http://dx.doi.org/10.1016/j. tranpol.2010.04.006

Dhingra, C., 2011, 'Measuring public transport performance: Lesson for developing countries', Sustainable Urban Transport Technical Paper Document 9, GIZ, Bonn.

Duarte, F. \& Rojas, F., 2012, 'Intermodal connectivity to BRT: A comparative analysis of Bogota and Curitiba', Journal of Public Transportation 15(2), 1-18.

Duarte, F. \& Ultramari, C., 2012, 'Making public transport and housing match: Accomplishments and failures of Curitiba's BRT', Journal of Urban Planning and Development 138(2), 183-194. http://dx.doi.org/10.1061/(ASCE)UP.19435444.0000107

Eboli, L. \& Mazulla, G., 2007, 'Service quality attributes affecting customer satisfaction for bus transport', Journal of Public Transport 10(3), 30-42. 
Eichhom, M., 2013, MyCiTi: Brilliant service delivery or irresponsible public planning, viewed 13 December 2013, from http://groundup.org.za/content/myciti-brilliantservice-delivery-or-irresponsible-public-planning

Ekinci, Y., 2004, 'An investigation of determinants of customer satisfaction', Tourism Analysis 8, 197-203.

Fen, Y. \& Lian, K., 2007, 'Service quality and customer satisfaction: Antecedents of customer's re-patronage intentions', Journal of Sunway Academy 4, 59-72.

Finn, B. \& Mulley, C., 2011, 'Urban bus service in developing countries and countries in transition: A framework for regulatory and institutional developments', Journa of Public Transportation 14(4), 89-107.

Foote, J., Stuart, G. \& Elmore-Yalch, R., 2001, 'Exploring customer loyalty as a transit performance measure', Journal of Transport Research 1753, 93-100.

Foster, S., 2013, Managing quality: Integrating the supply chain, Pearson Education, Harlow.

Garling, T., 2005, Changes of private car in response to travel demand management, Keynote lecture presented at the 3rd International Conference on Traffic \& Transport Psychology (ICTTP), Nottingham, UK, 05-09 September 2004.

Goodman, J., Laube, M. \& Schwenk, J., 2006, 'Curitiba's bus system is model for rapid transit', Urban Habitat: Race, Poverty and the Environment, Winter, 75-76

Govender, K., 2014, 'Public transport service quality in South Africa: A case study of bus and minibus services in Johannesburg', African Journal of Business Management 8(10), 317-326.

Greuning, V., 2012, Rea Vaya ticket sales steady, viewed 28 May 2014, from http:// www.reavaya.org.za/news-archive/october-2012/834-ticket-sales-steady

Hennig-Thurau, T. \& Klee, A., 1998, 'The impact of customer satisfaction and relationship quality on customer retention: A critical reassessment and model
development', Journal of Psychology and Marketing 14(8), 737-761. http:// development', Journal of Psychology and Marketing 14(8), 737-761. http://
dx.doi.org/10.1002/(SICI)1520-6793(199712)14:8<737::AID-MAR2>3.0.CO;2-F

Henser, D. \& Golob, T., 2008, 'Bus rapid transit systems: A comparative assessment', Journal of Transportation 35(4), 501-518. http://dx.doi.org/10.1007/s11116-0089163-y

Hensher, D., Stopher, P. \& Bullock, P., 2003, 'Service quality: Developing a service quality index in the provision of commercial bus contracts', Journal of Transport Research 37, 499-517.

Hildalgo, D. \& Graftieaux, P., 2008, 'Bus rapid transit systems in Latin America and Asia: Results and difficulties in 11 cities', Transportation Research 2072, 77-88.

Holtmann, B. \& Jansen, C., 2007, 'Safe society safe mobility', The challenges of implementing policy: 26th Annual Southern African Transport Conference, CSIR International Conference Centre, Tshwane, 09-12 July.

Iles, R., 2005, Public transport in developing countries, Elsevier, Amsterdam.

International Association of Public Transport (UITP), 2010, Symposium on Public Transportation in Indian Cities with special focus on bus rapid transit (BRT) system, Transportation
UITP, Delhi.

Jaisal, A., 2008, 'Customer satisfaction and service quality measurement in India call centres', Managing Service Quality 18(4), 405-416. http://dx.doi. India call centres', Managing Servic
org/10.1108/09604520810885635

Jarzab, J., Lightbody, J. \& Maeda, E., 2002, 'Characteristics of bus rapid transit projects: An overview', Journal of Public Transportation 5(2), 32-46.

Javid, M., Okamura, T., Nakamura, F. \& Wang, R., 2013, 'Comparison of commuters' satisfaction and preferences with public transport: A case of wagon services in Lahore, Jordan', Journal of Civil Engineering 7(4), 461-472.

Ji, J. \& Gao, X., 2010, 'Analysis of people's satisfaction with public transportation in Beijing', Habitat International 34, 464-468. http://dx.doi.org/10.1016/j. habitatint.2009.12.003

Kane, A., 2006, Transport problem associated with poverty in South Africa, Urban Transport Research Group UCT, Cape Town.

Kanyama, C., Linden, A. \& Lupala, J., 2004, Public transport in Dar-es-Salaam, Tanzania: Institutional challenges and opportunities for sustainable transport Tanzania: Institutional challenge
system, FOI/KTH, Stockholm.

Klein, M., 2014, Customer satisfaction is not customer loyalty, viewed 02 January 2014, from http://www.dmnews.com/customer-satisfaction-is-not-customerloyalty/article/313592/

Leland, K. \& Bailey, K., 1995, Customer service, IDG Worldwide, Foster City.

Levinson, H., Zimmerman, S., Clinger, J., Gast, J., Rutherford, S. \& Bruhn, E., 2003, Bus rapid transit implementation guidelines, TCRP Report 90, Transport Research Board, Washington, DC.

Litman, T., 2008, 'Valuing transit service quality improvements', Journal of Public Transportation 11, 43-62.
Malhotra, N., 2010, Marketing research: An applied orientation, Pearson Prentice Hall, Upper Saddle River.

Mashiri, M., Moeketsi, P. \& Baloyi, V., 2010, Increasing public transport market share in South Africa: The options, CSIR Public Passenger Transport, Pretoria.

Mazulla, G. \& Ebloi, L., 2006, 'A service quality experimental measure for public transport', Journal of European Transport 34, 42-53.

McKnight, C., Pagano, A. \& Paaswell, R., 1986, Using quality to predict demand for special transportation, VNU Science Press, Utrecht, pp. 423-441.

Mfinanga, D. \& Ochieng, M., 2006, 'Development of a model for accessing urban public transport level of service in cities of developing nations', African Journal of Science and Technology 7, 35-52.

Mobereola, D., 2009, Africa's first bus rapid transit scheme: The Lagos BRT-lite system, Sub-Saharan Africa Transport Policy Program Discussion Paper 9, SSATP, System,
Lagos.

Moreo, J., 1996, Delivering exceptional customer service, Knowledge Resources, Randburg.

Mokonyama, M., 2012, Public transport transformation, Proceedings of the 14th Annual African Renaissance Conference on Public Transport, Durban, 24-25 May, Department of Transport Publishing, Pretoria, pp. 1-17.

MyCiTi, 2013, Myciti profile: History, viewed 28 December 2013, from http://www. myciti.org.za/en/about/about-us/history/

MyCiTi, 2014, New routes see passenger numbers almost double, viewed 31 May 2014, from http://myciti.org.za/en/about/media-marketing/myciti-news/mycitipassenger-numbers-almost-double/

Nandan, S. \& Geetika, C., 2010, 'Determinants of customer satisfaction on service quality: A study of railway platforms in India', Journal of Public Transportation 13 97-112.

Nkurunzia, A., Zuideest, M., Brussel, M. \& Maarseveen, M., 2012, 'Modeling commuter preferences for the proposed bus rapid transit in Dar-es-Salaam', Journal of Public Transportation 15(2), 95-116.

Parasuraman, A., Zeithaml, V. \& Berry, L., 1985, 'A conceptual model of service quality and its implementation for future research', Journal of Marketing 14(49), 40-49.

Reichheld, F. \& Sasser, W., 1990, 'Zero defection: Quality comes to services', Harvard Business Review 68, 105-111.

Remenyi, D., Williams, B., Money, A. \& Swartz, E., 2009, Doing research in business and management, Sage, London.

Republic of South Africa, 2009, National Land Transport Act (Act No. 5 of 2009), Govement Gazette 32110, Government Printers, Pretoria.

Ryneveld, P., 2008, 15 Year review of public transport in South Africa with emphasis on metropolitan areas, Hunter van Ryneveld (Pty) Ltd, Pretoria.

Santos, E., 2011, Pioneer in BRT and urban planning, Lambert Academic Press, Saarbrucken.

Schade, J. \& Schlag, B., 2003, 'Acceptability of urban transport pricing strategies', Transportation Research 6, 45-61.

SPSS Statistics version 22, 2013, computer software, IBM, Chicago.

Statistics South Africa, 2012a, Municipal report on Census 2011: Gauteng, StatsSA, Pretoria, pp. 2-10.

Statistics South Africa, 2012b, Census 2011 municipal report: Western Cape, StatsSA, Pretoria, pp. 49-93.

Stradling, S., Carreno, M., Rye, T. \& Noble, A., 2007 'Passenger perceptions and the ideal urban bus journey experience', Journal of Transport Policy 14, 283-289. http://dx.doi.org/10.1016/j.tranpol.2007.02.003

Suzuki, H., Cervero, R. \& Luchi, K., 2013, Transforming cities with transit: Transit and land use integration for sustainable urban development, World Bank, Washington, DC.

Suzuki, H., Dastur, A., Moffatt, S., Yabjuk, N. \& Maryyama, H., 2010, Eco cities: Ecological cities as economic cities, World Bank, Washington, DC. http://dx.doi. org/10.1596/978-0-8213-8046-8

Ungerer, L. \& Daweti, M., 2007, Customer service in tourism, UNISA Press, Pretoria.

Vavra, G., 1997, Improving your measurements of customer satisfaction, ASQ Quality Press, Milwaukee.

Wallis, I. \& Currie, G., 2008, 'Effective ways to grow urban bus markets: A synthesis of evidence', Journal of Transport Geography 16, 418-427.

World Tourism Organization, 1985, Identification and evaluation of measures that ensures adequate quality of services, WTO, Madrid.

Zeinthaml, V.A., Bitner, M. \& Grembler, D., 2006, Service marketing: Integrating customer focus across the firm, McGraw-Hill, New York. 